\title{
Revision of the geological context of the Port-au-Prince metropolitan area, Haiti: implications for slope failures and seismic hazard assessment
}

\author{
M. Terrier ${ }^{1}$, A. Bialkowski ${ }^{1}$, A. Nachbaur ${ }^{2}$, C. Prépetit $^{3}$, and Y. F. Joseph ${ }^{4}$ \\ ${ }^{1}$ BRGM, 3 Avenue Claude Guillemin, BP 36009, 45060 Orléans CEDEX 2, France \\ ${ }^{2}$ BRGM, Villa Bel Azur, 4 Lot. Miramar, Route de la pointe des Nègres, 97200 Fort-de-France, Martinique, \\ French West Indies \\ ${ }^{3}$ BME, P.O. Box 2174, Port-au-Prince, Haiti \\ ${ }^{4}$ LNBTP, Rue Toussaint Louverture, \#27, Port-au-Prince, Haiti
}

Correspondence to: M. Terrier (m.terrier@brgm.fr)

Received: 19 September 2013 - Published in Nat. Hazards Earth Syst. Sci. Discuss.: 18 February 2014

Revised: 13 August 2014 - Accepted: 27 August 2014 - Published: 26 September 2014

\begin{abstract}
Following the earthquake of 12 January 2010 in the Port-au-Prince area, the Haitian government, in close cooperation with BRGM, the French geological Survey, decided to undertake a seismic microzonation study of the metropolitan area of the capital in order to take more fully into account the seismic risk in the urbanization and planning of the city under reconstruction. As the first step of the microzonation project, a geological study has been carried out. Deposits of Miocene and Pliocene formations in a marine environment have been identified. These deposits are affected by the Enriquillo-Plantain Garden N80 $\mathrm{E}$ fault system and $\mathrm{N} 110^{\circ} \mathrm{E}$ faults. Tectonic observations and morphological analysis indicate Quaternary activity of several faults mapped in the area of Port-au-Prince. These faults have a $\mathrm{N} 110^{\circ}$ trend and show a reverse-sinistral strike-slip motion. Moreover, on the basis of these geological results and of new topographical data, a hazard assessment of ground movements has been made. Along with the map of active faults, the hazard map of ground movements is an integral component of the seismic microzonation study.
\end{abstract}

\section{Context}

On 12 January 2010 Haiti was struck by one of the most violent earthquakes to have affected the country within the last 2 centuries. According to the DEC
(Disasters Emergency Committee; http://www.dec.org.uk/ haiti-earthquake-facts-and-figures, last access: 2014), the earthquake left 220000 dead, 300000 injured, and over a million homeless. Port-au-Prince, the capital city of Haiti, and its metropolitan area have suffered massive losses. The study of the historical archives (Bakun et al., 2012) indicates that the island of Hispaniola has been hit by several major earthquakes over the past centuries. These earthquakes are concentrated in the northern or in the southern parts of the island. In addition to the 2010 earthquake, Port-au-Prince had already been destroyed by the earthquakes of 1751 and 1770 .

In order to better integrate seismic risk parameters into the reconstruction and development planning of the capital city, a seismic microzonation study started in 2011 , with a focus on the Port-au-Prince metropolitan area. The work has been carried out by two Haitian institutions, the Laboratoire National du Bâtiment et des Travaux Publics (LNBTP) and the Bureau des Mines et de l'Energie (BME) as well as BRGM, the French Geological Survey. The selected zoning scale is $1: 25000$ over the metropolitan area as a whole and $1: 10000$ for strategic sectors. The zonation work takes into account the seismic ground motion in the bedrock (regional hazard) and modifications produced by this motion in relation with the local topographic and lithologic conditions (location and characterization of site effects and induced effects). The techniques implemented for this mapping initiative rely on available scientific knowledge, completed and updated by 


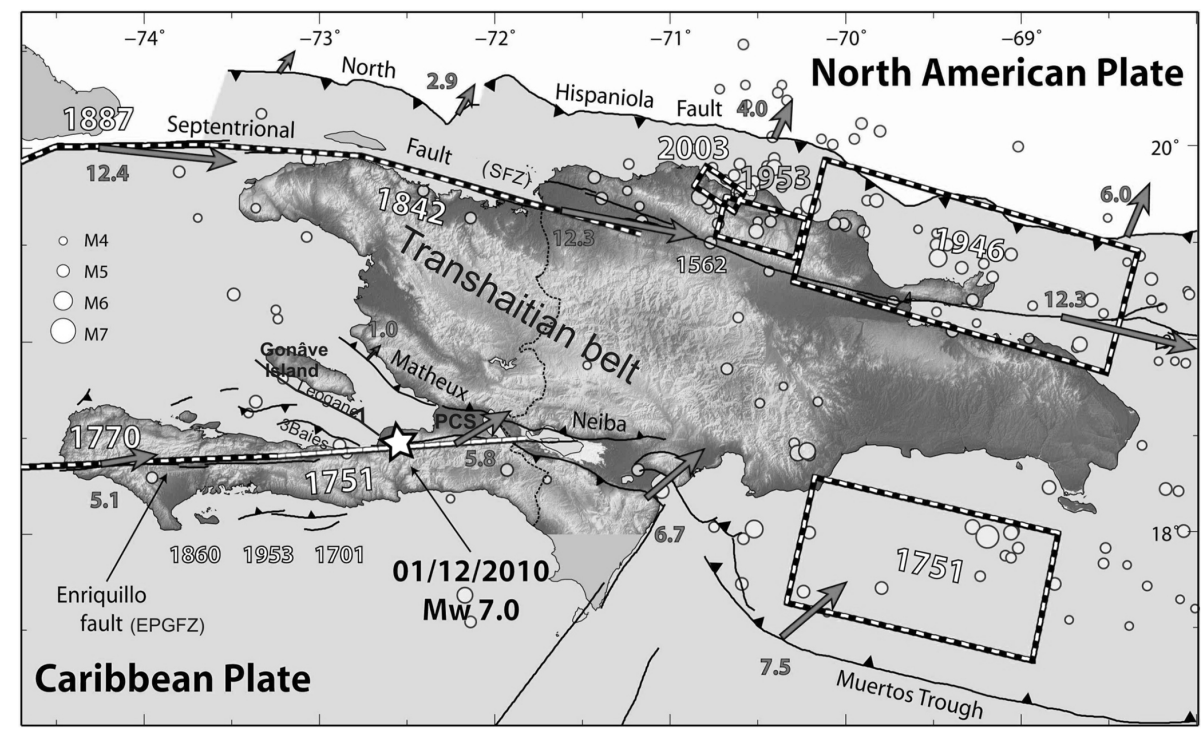

Figure 1. Location of historical rupture zones and indications (arrows) of the active slip rates (in $\mathrm{mm} \mathrm{yr}^{-1}$ ) derived from geodetic measurements (modified from Calais et al., 2010; http://web.ics.purdue.edu/ ecalais/haiti/context/) (PCS: Plaine de Cul-de-Sac).

on-site investigations (geological, geophysical and geotechnical) and/or modeling. Intended for decision-makers, development planners, structural engineers and architects, but also for the public at large, this seismic microzonation work is of major interest both for the rebuilding of devastated zones of the Haitian territory and for preventive actions within the framework of a well-managed development planning policy.

\section{The geodynamic background}

The island of Hispaniola is occupied by the Republic of Haiti to the west and by the Dominican Republic to the east. With the islands of Cuba, Jamaica and Puerto Rico it goes to make the Greater Antilles archipelago. The latter marks the boundary between the North American and the Caribbean tectonic plates. The main motion between the two plates amounts to a relative mean rate of $2 \mathrm{~cm} \mathrm{yr}^{-1}$, with a converging direction of these two plates of $\mathrm{N} 70^{\circ} \mathrm{E}$ that is oblique with respect to the E-W plate margins (Mann et al., 2002). On the island of Hispaniola, two great fault systems mark the boundary running along the north of Hispaniola and the EnriquilloPlantain Garden fault zone (EPGFZ) to the south (see Fig. 1).

The SFZ cuts across the north of Haiti and the Dominican Republic and extends westward beyond southern Cuba. The mean slip measured is $12 \mathrm{~mm} \mathrm{yr}^{-1}$ (Calais et al., 2010; http://web.ics.purdue.edu). The strongest known earthquake associated with this fault system, having a magnitude estimated at 8 , is that of 7 May 1842. This event caused the death of half of the population and considerable damage in several towns in northern Haiti (Bakun et al., 2012).

The EPGFZ runs along the southern Peninsula of Haiti. To the west, this fault system reaches the island of Jamaica (the Plantain Garden plain). To the east of the Haiti and Dominican Republic border, the EPGFZ ends at the Muertos fault system, which corresponds to the subduction of the Caribbean plate beneath the Greater Antilles archipelago. The mean slip measured on the EPGFZ is $7( \pm 2) \mathrm{mm} \mathrm{yr}^{-1}$ (Calais et al., 2010; website http://web.ics.purdue.edu). In addition to the 12 January 2010 seismic event, other major historical earthquakes from throughout the last centuries (1701, 1751, 1770, and 1860) have been ascribed to this structure. According to Bakun et al. (2012), the 1751 event had a magnitude of at least 7.4, and for the one in 1770, the magnitude is estimated at 7.5.

In the center of the island of Hispaniola, a number of large active thrust faults trending NW-SE are visible in the present-day morphology (Mann et al., 1995; Pubellier et al., 2000). These faults are structuring the Transhaitian Belt. To the north, they are connecting to the SFZ and, to the south, to the Muertos fault system. The thrust of the Matheux range corresponds to the northern boundary of the Plaine de Culde-Sac (see Fig. 1). This is the main structure of the Transhaitian Belt. According to GPS data, the mean measured slip on this thrust is approximately $1 \mathrm{~mm} \mathrm{yr}^{-1}$ (Calais et al., 2010; website http://web.ics.purdue.edu). Seismic profiles implemented in the Gulf of La Gonâve (Mann et al., 1995) reveal the presence of folds and reverse faults dating in age from the Miocene to the Quaternary, which make the active frontal edge of the Transhaitian Belt. The reverse motion of the Transhaitian fault system partially compensates the oblique component of the convergence of the North-American and Caribbean plates with respect to their edges.

The 12 January 2010 earthquake reached a magnitude Mw of 7.1; its focal depth was $13 \mathrm{~km}$. The epicenter was 


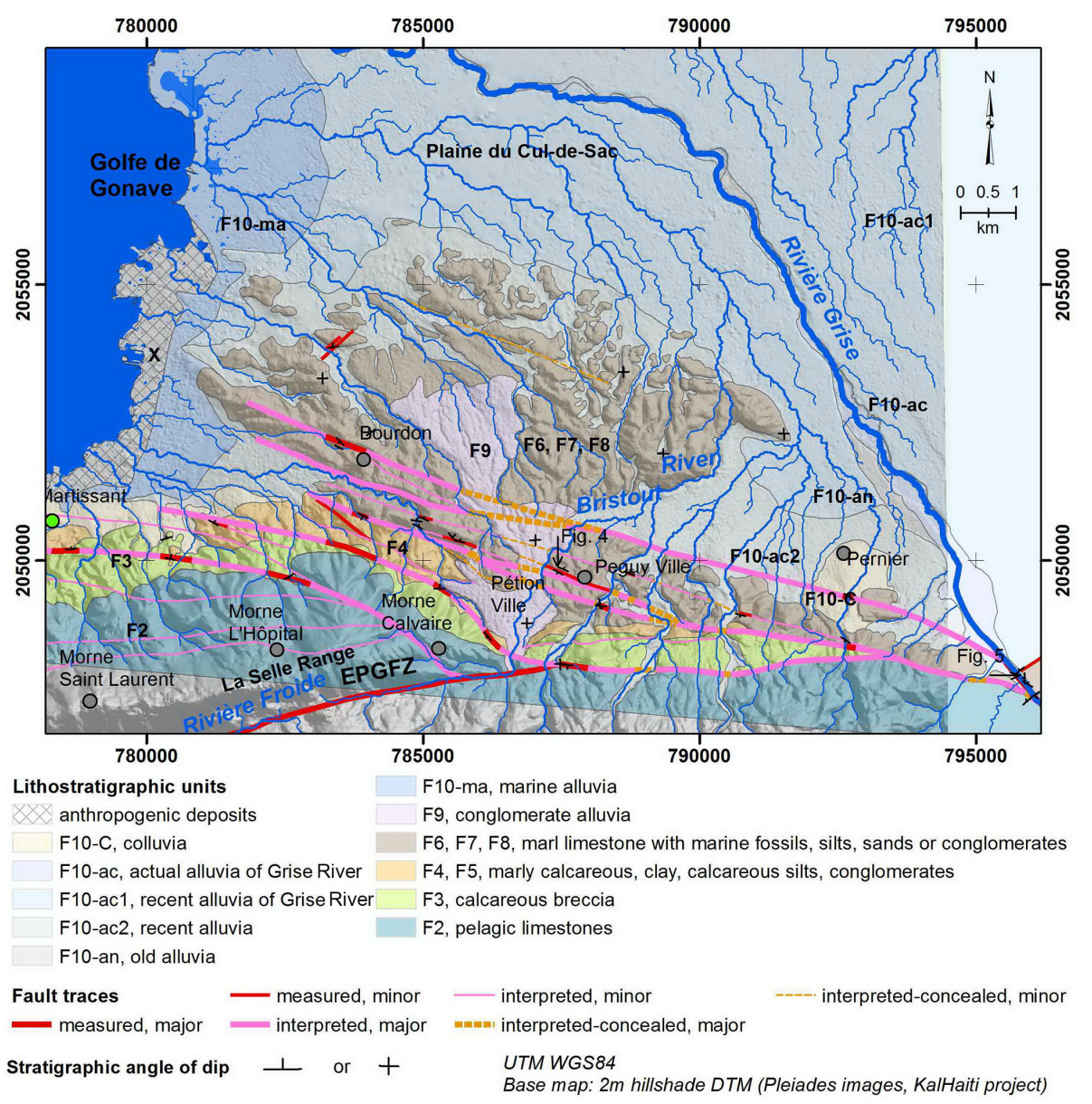

Figure 2. Geological map of the Port-au-Prince metropolitan area.

located between the island of La Gonâve and the eastern end of Haiti's southern peninsula (see Fig. 1). The focal mechanisms computed for the main shock and the aftershocks, radar interferometry measurements, and GPS data indicate motion along a fault striking ENE-WSW $\left(\mathrm{N} 71^{\circ} \mathrm{E}\right)$, that is north-dipping with a reverse left-lateral component (Calais et al., 2010). Thus, this fault is slightly oblique with respect to the trend of the EPGFZ (N80 ${ }^{\circ}$ ) and lies to the north of this zone. Named the Léogâne fault (Calais et al., 2010), it is interpreted as being a blind thrust. According to the analysis of aftershocks of the 12 January 2010 event, the main rupture on the Léogâne fault appears to have triggered a reverse movement on a $\mathrm{N} 120^{\circ} \mathrm{E}$ fault (the Trois-Baies Fault), interpreted as a secondary fault of the EPGFZ (Mercier de Lépinay et al., 2011), and the reactivation at depth in a leftlateral strike of the main fault plane of the EPGFZ (Hayes et al., 2010; Douilly et al., 2012).

\section{Geological study of the Port-au-Prince metropolitan area}

The map of lithological facies of the Port-au-Prince metropolitan area constitutes the essential input data controlling both the soil (and the bedrock) responses to seismic vibrations and the susceptibility to ground movements. Before the study, the geological information available for the Portau-Prince area was relatively poor. It mainly consisted of a geological map of Haiti at 1:250000 scale (Momplaisir and Boisson, 1987) and the recent geomorphological sketch map by Bachhuber et al. (2010), at 1:50000 scale.

In order to make a reliable seismic microzonation mapping, it was necessary to improve the knowledge of the geological context of the area under study. Our geological study consisted of observing several dozen of outcrops, supplemented by the analysis of geotechnical boreholes drilled earlier, together with the interpretation of aerial photographs from 2002, plus the analysis of the digital terrain model with $2 \mathrm{~m}$ pixels to a side calculated from 2012 Pleiades satellite images (KalHaiti, SERTIT/CNES, 2012), SPOT 2010 orthoimages, and 3-D-view satellite images of various dates under Google Earth. 


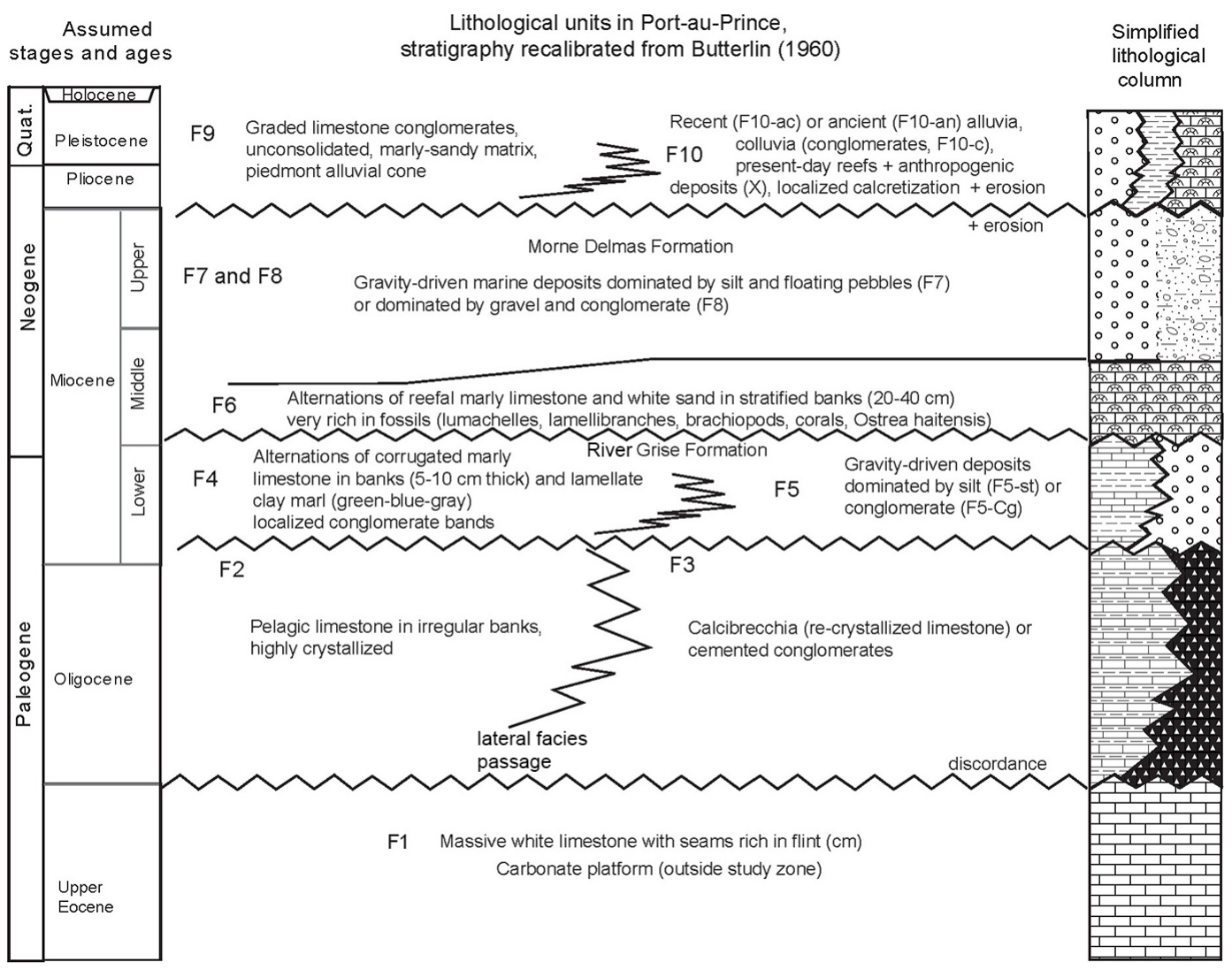

Figure 3. Litho-stratigraphic synthesis for the Port-au-Prince study sector; stratigraphic sequence based on the work by Butterlin (1960).

\subsection{Mapping of the lithological facies}

The Port-au-Prince metropolitan area lies in the Cul-de-Sac alluvial plain (see Fig. 2). Eastwards, the urban area ends near the River Grise, while to the west, the city is bordered by the sea. In a southerly direction, the city abuts on the mountain peaks Mornes de Saint-Laurent and Mornes de l'Hôpital in the La Selle Mountain range. These peaks are bounded to the south by the River Froide, whose course is, in turn, determined by the EPGFZ.

The various lithological facies found in the field have been classified into 10 types or units ranging from the oldest to the most recent: F1 (Upper Eocene) through F10 (PlioQuaternary to Present) (Fig. 3). The estimated ages of these units are derived from the work of Butterlin (1960). The rocky substratum consists of limestones, silts, marls or conglomerates (or breccia). Sandy facies are rarely met. Marls are frequently associated with limestones to form "marlylimestone" alternations more or less rich in marine fossils depending on the site. The present-day topography is largely the result of the Mio-Pliocene orogeny and of the activation of the faults that delimit tectonic blocks, atop which Quaternary and recent erosion has occurred.

At the peaks of Saint-Laurent and Hôpital, Eocene to Oligocene limestones outcrop to the south and Miocene con- glomerates to the north. The main orographic axis is $\mathrm{N} 80^{\circ} \mathrm{E}$, parallel to the EPGFZ. Between the Cul-de-Sac alluvial plain to the north and the northern slope of Morne Hôpital, small hills of secondary origin mark the topography at around $\mathrm{N} 110^{\circ} \mathrm{E}$. The marly limestones and Mio-Pliocene marls or silts form at the base of these hilly topographies. Here, the stratigraphic surfaces of these formations trend WNW-ESE and dip steeply (angle greater than $45^{\circ}$ ) towards the north or the south (see Fig. 2). These reliefs are bounded, to the east and north, by the alluvial formations of the River Grise, and to the west by marine alluvia. To the south, colluvial deposits or dejection cones cover these reliefs in places. The colluvia in place are mostly fairly shallow, with thicknesses generally ranging between 0.1 and $0.5 \mathrm{~m}$ on more rugged relief, and from 0.5 to $1 \mathrm{~m}$ on average in less hilly areas. These remobilized surface deposits can reach thicknesses of several meters in narrow valley bottoms.

In Fig. 3, the analysis of the Miocene to Pliocene terrains in the Plaine de Cul-de-Sac shows (i) deep water to sublittoral marine deposits (marly limestones, mudstones, finegrained sandstones and silts) characteristic of low-energy environments and (ii) sharp intercalation of detritic formations related to sequences of sandy and gravelly to silty turbiditic deposits (conglomerates). These formations correspond to marine deposits with a proportionally variable 


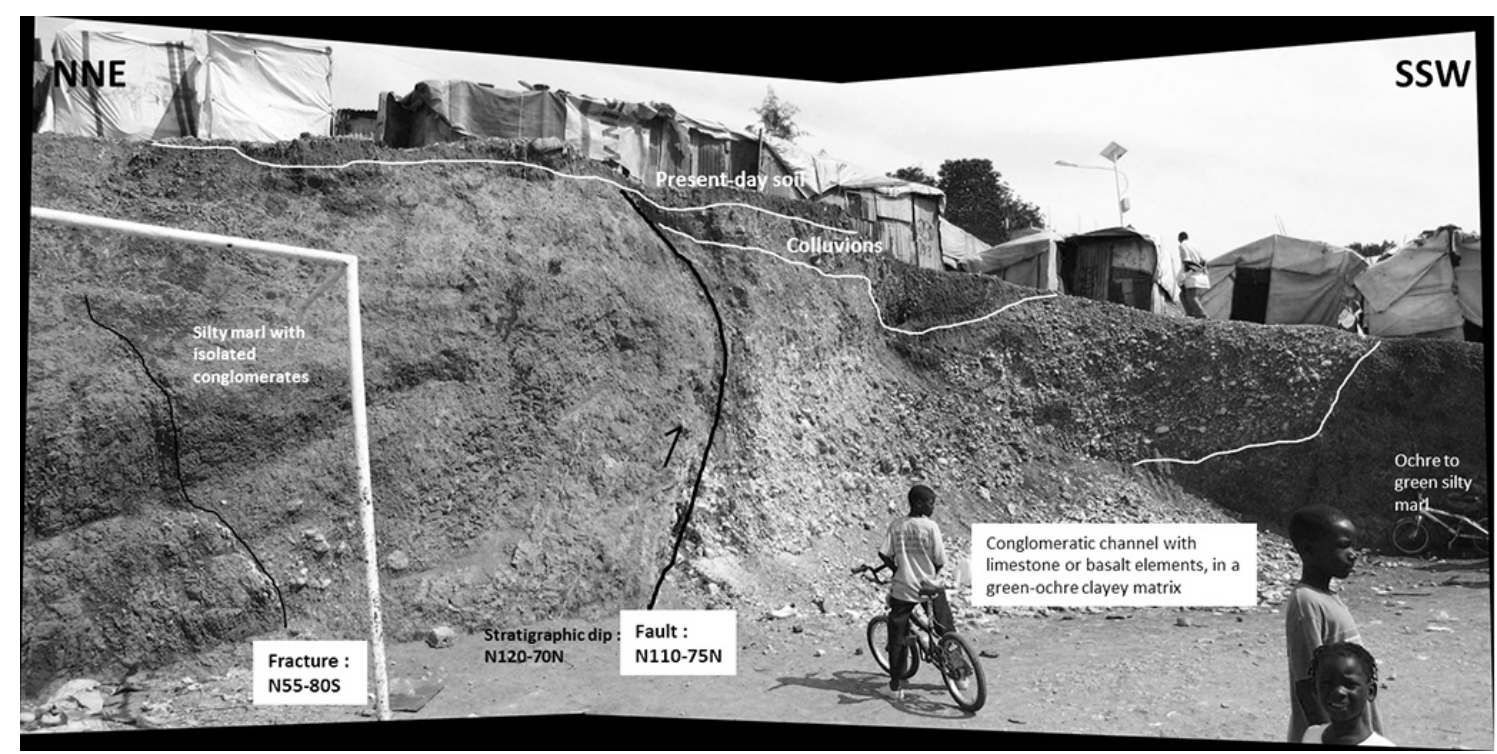

Figure 4. Fault contact in Mio-Pliocene terrains between the deposits of sandy, ochre-colored silts and conglomerates; location: Fig. 2 (Photo M. Terrier).

limestone component, overlain by flysch sequences that become increasingly regular and frequent at the end of the Miocene and the beginning of the Pliocene. These sharp detritic intercalations, considered to be tectonic in origin, are ascribed to the continual activation during the Mio-Pliocene of the faults bounding the Port-au-Prince plain to the south.

These Miocene and Pliocene formations are several hundreds of meters thick, with a possible high exceeding $1000 \mathrm{~m}$, on the strength of the marine seismic profiles in the Gulf of Gonâve (Mann et al., 1995) as well as the borehole drilled in the Plaine de Cul-de-Sac by ATLANTIC REFINING in 1947 (Momplaisir, 1986).

\subsection{Fault mapping}

Regarding fault mapping, this work was performed by observing outcropping fault planes (Fig. 2), supplemented by the interpretation of morphological data. A majority of the fault planes measured are trending E-W to NW-SE. Most of them show reverse left-lateral activation (Fig. 4). In several locations, the contact via the fault between quaternary alluvia and Miocene to Pliocene formations is visible (Fig. 5).

In the central part of the metropolitan area of Portau-Prince, a conglomerate formation made of uncemented, graded, polymetric limestone elements embedded in a marly sandy matrix overlies the Mio-Pliocene marly limestone and silt formations. This formation corresponds to a piedmont alluvial cone which was probably deposited between the end of the Pliocene and the early Quaternary. The hydrographic system responsible for this deposit is to be sought in the limestone relief to the south, quite probably in the upstream portion of the Bristout River catchment area (Fig. 6). The debris cone is characterized by three distinct assemblages, interpreted as successive deposits from the drainage basin. The oldest part is located in the north; in the south, the most recent part is still fed by the present-day Bristout River. Based on the central axis of the north and center sections of the cone, the hypothesis of a $1000 \mathrm{~m}$ offset cannot be excluded (Fig. 6). This would indicate a horizontal displacement rate of $0.6( \pm 0.2) \mathrm{mm} \mathrm{yr}^{-1}$ for the WNW-ESE fault systems mapped at this location. This estimate is compatible with the values from GPS measurements of the compressive deformations of the Transhaitian Belt (Fig. 1).

Furthermore, between the Musseau and Chavannes districts, the hydrographic network presents a number of inflections in hydrographic drains following a WNW-ESE trend. These inflections may locally have sizes up to $300 \mathrm{~m}$. This mean value is coherent with the hypothesized horizontal displacement rate indicated above, bearing in mind that in this instance, these are markers of more recent date (middle to upper Quaternary).

\section{Hazard assessment of ground movements}

\subsection{Method used}

Ground movements may be triggered by seismic vibrations. This is why they must be analyzed in the seismic microzonation process as potential site effects. In addition to local topographic conditions, the lithologic nature of the terrains constitutes one of the main environmental factors governing ground stability.

For this part of the study, the main steps were (i) an inventory of the ground movements in the region of Port-au-Prince (location, type of instability, geological and morphological 


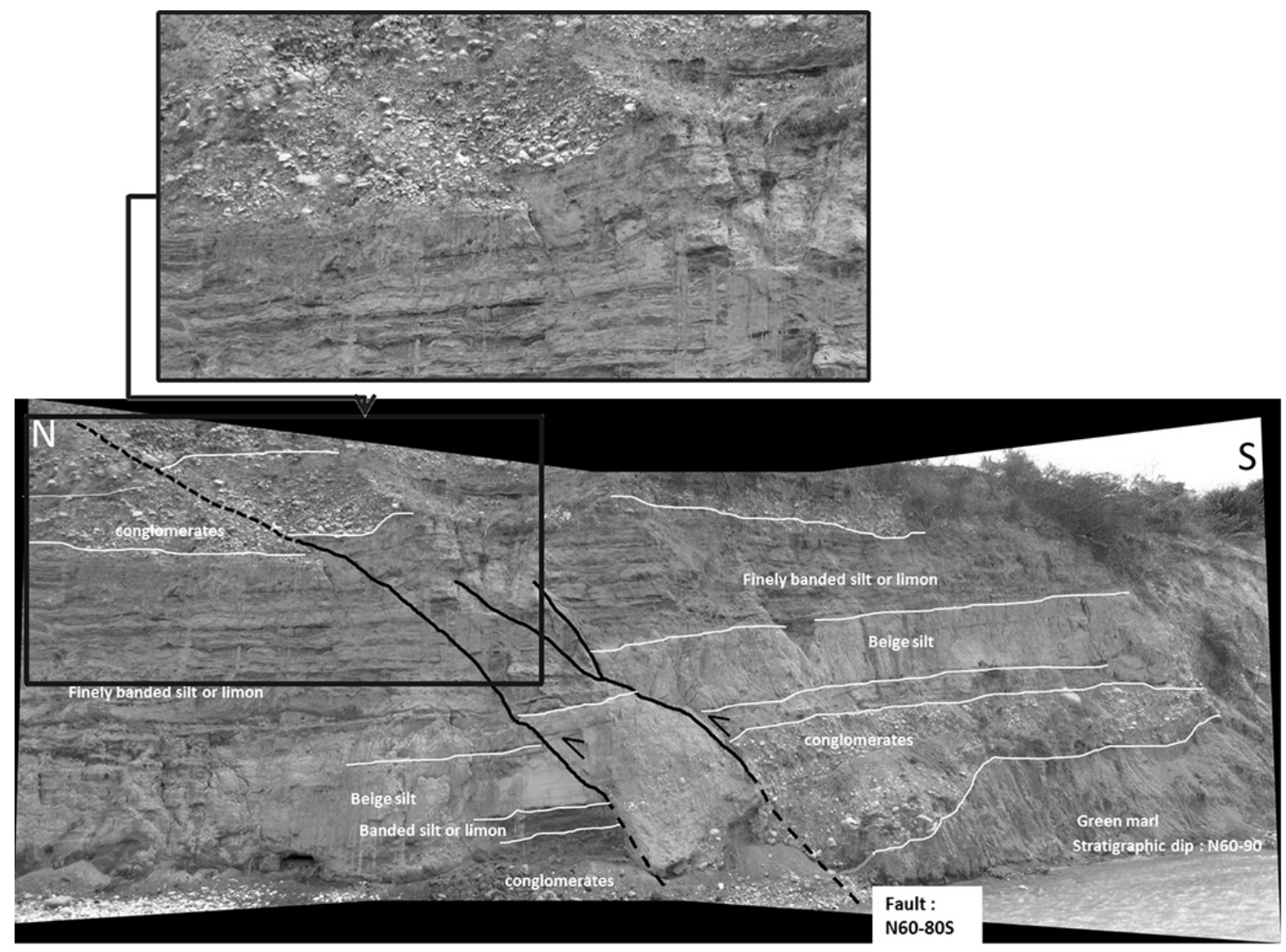

Figure 5. Reverse faults trending NE-SW, visible along River Grise in the Quaternary conglomerates and silt deposits; location: Fig. 2 (Photo M. Terrier).

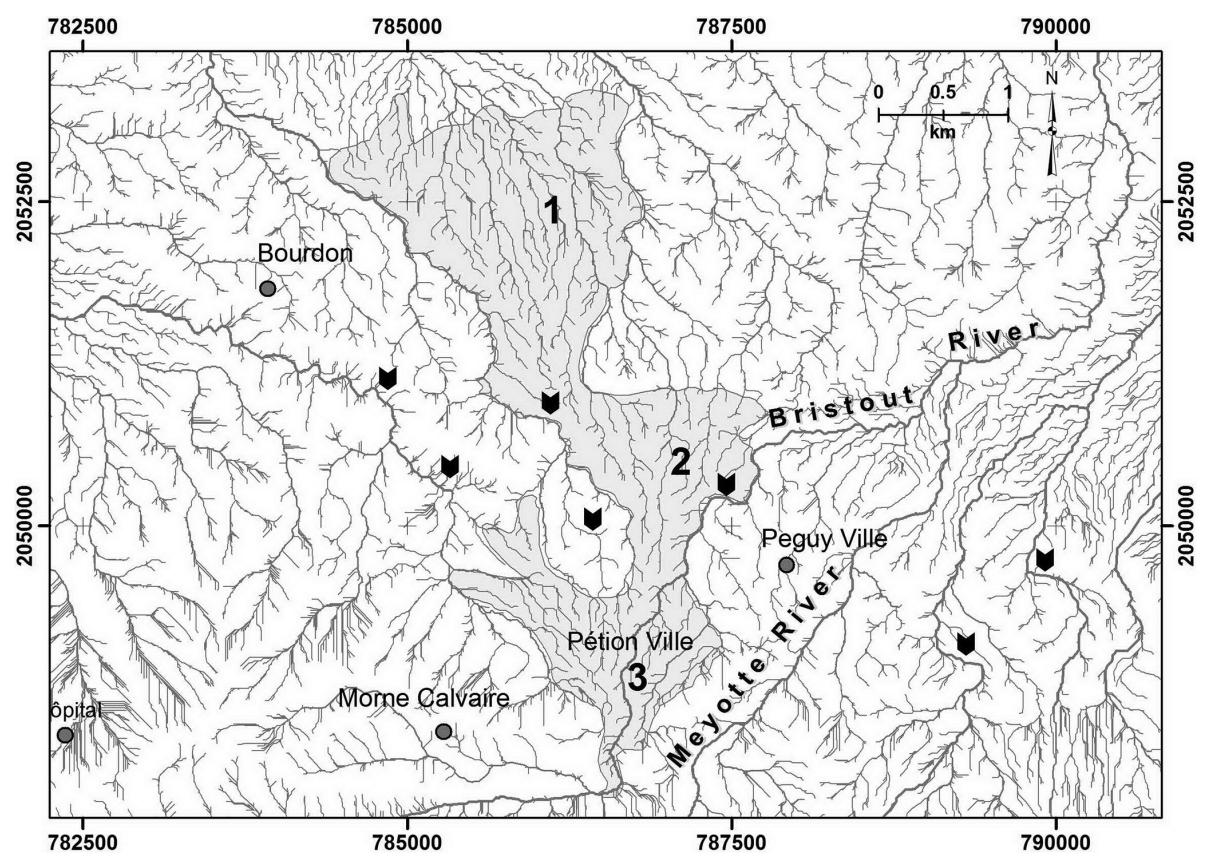

Figure 6. Hydrographic network calculated from the Pleiades DTM: zoom on the catchment area of the Bristout and Meyotte rivers. Numbers 1 to 3: successive segments of the alluvial cone (ranging from the oldest to the youngest); black arrows: inflexions of the water course; grey area: F9 unit. 
Table 1. Characteristics of the most important ground movement inventories over the Port-au-Prince 2 metropolitan area (L: landslide; $\mathrm{R}$ : rockfall; B: bank erosion; ?: uncertain data )

\begin{tabular}{|c|c|c|c|c|c|c|c|c|c|}
\hline Name & $\begin{array}{l}\text { Type of } \\
\text { MVT }\end{array}$ & Damage & Description & Lithology & $\begin{array}{l}\text { Triggering } \\
\text { factor }\end{array}$ & Date & Observation & Seen & Size \\
\hline $\begin{array}{l}\text { Musseau, } \\
\text { imp Avalon }\end{array}$ & $\mathrm{L}$ & $\begin{array}{l}\text { Several houses } \\
\text { destroyed }\end{array}$ & $\begin{array}{l}30 \mathrm{~m} \text { high by } 50 \mathrm{~m} \text { wide, } \\
\text { initial slope }>37^{\circ} \text {. } \\
\text { Bordered at the base by the } \\
\text { Musseau ravine }\end{array}$ & $\begin{array}{l}\text { Limey channel silt } \\
\text { isolated from con- } \\
\text { glomerates (F7, F8). } \\
\text { Marly layer at the } \\
\text { base (F6?) }\end{array}$ & $\begin{array}{l}\text { Heavy } \\
\text { rains }\end{array}$ & 2008 & $\begin{array}{l}\text { Accentuation in } 2008 \text { of } \\
\text { an earlier landslide }\end{array}$ & Yes & $\begin{array}{l}\text { Large } \\
\text { to very } \\
\text { large }\end{array}$ \\
\hline Djobel1 & $\mathrm{L}$ & $\begin{array}{l}7 \text { fatalities and } \\
11 \text { houses } \\
\text { destroyed }\end{array}$ & $\begin{array}{l}\text { Scarp } 25 \mathrm{~m} \text { high } \\
\text { by } 50 \mathrm{~m} \text { wide }\end{array}$ & $\begin{array}{l}\text { Brown argillaceous } \\
\text { silts with more } \\
\text { indurated levels of } \\
\text { very fine sand }\end{array}$ & $\begin{array}{l}\text { Heavy } \\
\text { rains }\end{array}$ & 2003 & Triggered in 2001 & Yes & $\begin{array}{l}\text { Large } \\
\text { to very } \\
\text { large }\end{array}$ \\
\hline Djobel3 & $\mathrm{L} / \mathrm{R}$ & None & $\begin{array}{l}\text { Subvertical scarp. Rock- } \\
\text { slide over a width of } 40 \mathrm{~m} \\
\text { and a height of } 60 \mathrm{~m}\end{array}$ & $\begin{array}{l}\text { Poorly consolidated } \\
\text { conglomerate banks }\end{array}$ & $\begin{array}{l}\text { Heavy } \\
\text { rains, } \\
\text { ravine }\end{array}$ & $\begin{array}{l}\text { Après } \\
2002\end{array}$ & $\begin{array}{l}\text { Bordered at the base } \\
\text { by a ravine }\end{array}$ & Yes & $\begin{array}{l}\text { Large } \\
\text { to very } \\
\text { large }\end{array}$ \\
\hline Djobel2 & $\mathrm{L} / \mathrm{R}$ & None & $\begin{array}{l}\text { Scarp } 40 \mathrm{~m} \text { high. Rockslide } \\
\text { over a width of } 10 \mathrm{~m}\end{array}$ & & $\begin{array}{l}\text { Heavy } \\
\text { rains }\end{array}$ & - & $\begin{array}{l}\text { Slope of } \\
\text { approximately } 35^{\circ}\end{array}$ & Yes & $\begin{array}{l}\text { Inter- } \\
\text { medi- } \\
\text { ate }\end{array}$ \\
\hline Marcadieu & $\mathrm{L}$ & Road blocked & $\begin{array}{l}\text { Rockslide over a height of } \\
40 \mathrm{~m} \text { and a width of } 40 \mathrm{~m}\end{array}$ & $\begin{array}{l}\text { Poorly consolidated } \\
\text { conglomerate banks }\end{array}$ & $\begin{array}{l}\text { Heavy } \\
\text { rains, } \\
\text { ravine }\end{array}$ & $1987 ?$ & $\begin{array}{l}\text { Bordered at the base by } \\
\text { the Bois de Chaine } \\
\text { ravine }\end{array}$ & Yes & Large \\
\hline $\begin{array}{l}\text { Vivy } \\
\text { Mitchell } 2\end{array}$ & $\mathrm{~L}$ & $\begin{array}{l}5 \text { houses } \\
\text { destroyed, } \\
\text { some } 10 \\
\text { houses display- } \\
\text { ing cracking }\end{array}$ & $\begin{array}{l}125 \mathrm{~m} \text { long by } 30 \mathrm{~m} \text { high, } \\
\text { over } 100000 \mathrm{~m}^{3} \text {. } \\
\text { Moderate slope }\left(<20^{\circ}\right)\end{array}$ & $\begin{array}{l}\text { Marly limestone } \\
\text { (F6?) overlain by cal- } \\
\text { cretization at the sum- } \\
\text { mit. Same dip as the } \\
\text { topography }\end{array}$ & $\begin{array}{l}\text { Heavy } \\
\text { rains }\end{array}$ & $>2002$ & $\begin{array}{l}\text { Triggered in } 1998 . \\
\text { Clearly visible from } \\
\text { DTM shading }\end{array}$ & Yes & $\begin{array}{l}\text { Large } \\
\text { to very } \\
\text { large? }\end{array}$ \\
\hline $\begin{array}{l}\text { Vivy } \\
\text { Mitchell } 1\end{array}$ & $\mathrm{~L}$ & $\begin{array}{l}\text { Several houses } \\
\text { destroyed or } \\
\text { with cracking }\end{array}$ & $\begin{array}{l}\text { Landslide scar revealed } \\
\text { over } 60 \mathrm{~m} \text {. Moderate } \\
\text { slope }\left(<20^{\circ}\right)\end{array}$ & $\begin{array}{l}\text { Marly limestone } \\
\text { (F6?) overlain by cal- } \\
\text { cretization at the sum- } \\
\text { mit. Same dip as the } \\
\text { topography }\end{array}$ & $?$ & $\begin{array}{l}\text { Post- } \\
2002\end{array}$ & $\begin{array}{l}\text { Same configuration as } \\
\text { Vivy Mitchell } 2 .\end{array}$ & Yes & Large \\
\hline $\begin{array}{l}\text { Boulard/ } \\
\text { Acacia }\end{array}$ & $\mathrm{L}$ & $\begin{array}{l}\text { Cracking in } \\
\text { some } 30 \\
\text { houses }\end{array}$ & - & - & $\begin{array}{l}\text { Micro- } \\
\text { earthquake }\end{array}$ & 2003 & $\begin{array}{l}\text { Information by word-of- } \\
\text { mouth. Nothing in the } \\
\text { field. Intensely built-up } \\
\text { area. Gentle slope }\end{array}$ & No & Large? \\
\hline
\end{tabular}

context); (ii) depending on the type of ground movements and based on past events, an analysis of predisposing factors (involved lithology, slopes value); (iii) preliminary mapping of the susceptibility of the land for instability; (iv) study in the field and analysis of aerial photographs in 3-D vision (definition of the different levels of hazard, and mapping of the boundaries of the hazard zones); and (v) restitution under a GIS of the hazard map.

A geological map made within the framework of the microzonation project, the digital terrain model calculated using Pleiades satellite images (KalHaiti, SERTIT/CNES, 2012), and the inventory of ground movements make up the cartographic reference data for the hazard assessment of ground movements. As attested by the past ground movements listed in Table 1, Port-au-Prince has often had to grapple with slope instabilities. The inventory of ground movements results from on-site observations, interpretation of aerial photographs (especially for the instability triggered by the earthquake of 2010) and local testimonies. Among the 40 or so events recorded in the area, 19 are documented by precise data such as location, lithological facies and the instability's geometry. For the remainder, it generally consists of eyewitness accounts indicating events triggered by the 2010 earthquake. These events fall into two main categories: landslides and rockfalls (see Table 1). The extent of the phenomena has been estimated from observations in the field and/or by interpretation of aerial photographs. In the area under study, identified landslides can reach large to very large volumes (hundreds of thousands of cubic meters to more than a million cubic meters, while the size of rockfall events is more limited. Rockfalls up to $10000 \mathrm{~m}^{3}$ are scarce.

Landslides generally involve marly limestone formations (F4, F5 and F6, cf. Fig. 3), which may be overlain by more recent layers of deposits (F7 and F8), while rockfall events concern mainly consolidated rocky layers (such as F3 and F2). In a few instances, calcretizations may be at issue (they can be up to $1 \mathrm{~m}$ thick) observed at the roof of the Morne Delmas geological formation (F6 to F8) or the shelly limestone banks (F6) in the marly limestone alternations.

While the lithological nature of the rocks largely conditions the type and the extent of potential ground movement, the hillslope also takes a significant part in the ground instability assessment. Other factors also influence the susceptibility of hillside instabilities. In any case, they are often difficult to integrate at the scale of this study. Among them, are, for example, structural data (as the dip of stratigraphic 
Table 1. Continued.

\begin{tabular}{|c|c|c|c|c|c|c|c|c|c|}
\hline Name & $\begin{array}{l}\text { Type of } \\
\text { MVT }\end{array}$ & Damage & Description & Lithology & $\begin{array}{l}\text { Triggering } \\
\text { factor }\end{array}$ & Date & Observation & Seen & Size \\
\hline Rue Rosa & $\mathrm{R}$ ? & - & $150 \mathrm{~m}$ long by $10 \mathrm{~m}$ wide & - & $?$ & $?$ & - & No & $\begin{array}{l}\text { Inter- } \\
\text { mediate }\end{array}$ \\
\hline $\begin{array}{l}\text { Ravine } \\
\text { Bristout }\end{array}$ & B & Houses & - & Alluvia (F10) & $?$ & $?$ & - & No & $\begin{array}{l}\text { Limited } \\
\text { to inter- } \\
\text { mediate }\end{array}$ \\
\hline $\begin{array}{l}\text { Morne } \\
\text { Calvaire }\end{array}$ & $\mathrm{R}$ & None & $\begin{array}{l}\text { Blocks measuring } \\
\text { approximately } 1 \mathrm{~m}^{3}\end{array}$ & Calcibrecchia (F3) & $\begin{array}{l}\text { Earth- } \\
\text { quake }\end{array}$ & $?$ & - & No & Limited \\
\hline Desermite & B & Houses & Deposit of detritic material & Calcibrecchia (F3) & $?$ & $?$ & - & No & Limited \\
\hline $\begin{array}{l}\text { PanAméri- } \\
\text { caine_2 }\end{array}$ & $\mathrm{L}$ & - & Suspected landslide & $\begin{array}{l}\text { Marly limestone } \\
(\mathrm{F} 5, \mathrm{~F} 6, \mathrm{~F} 7, \mathrm{~F} 8)\end{array}$ & $?$ & $?$ & $\begin{array}{l}\text { Gabion retaining wall up- } \\
\text { hill from the highway } \\
\text { and stabilization wall be- } \\
\text { low }\end{array}$ & Yes & $\begin{array}{l}\text { Inter- } \\
\text { mediate? }\end{array}$ \\
\hline $\begin{array}{l}\text { RivBois } \\
\text { DeChaine }\end{array}$ & $\mathrm{L}$ & - & $\begin{array}{l}\text { Over some } 100 \mathrm{~m} \text { along the } \\
\text { Bois de Chaine ravine and } \\
20 \mathrm{~m} \text { in height. Probably } \\
\text { the same configuration as } \\
\text { Marcadieu. }\end{array}$ & $\begin{array}{l}\text { Recent formations } \\
\text { overlying the Delmas } \\
\text { formation? }\end{array}$ & $\begin{array}{l}\text { Rain, } \\
\text { ravine? }\end{array}$ & $\begin{array}{l}\text { Prior to } \\
2010\end{array}$ & $\begin{array}{l}\text { Niche of plucking visible } \\
\text { from the Rue Panaméri- } \\
\text { caine. Probably triggered } \\
\text { by the action of the } \\
\text { ravine }\end{array}$ & Yes & $\begin{array}{l}\text { Inter- } \\
\text { mediate } \\
\text { to large }\end{array}$ \\
\hline Meyotte & $\mathrm{L}$ & - & $\begin{array}{l}\text { Undulating terrain } \\
\text { observed on the hillside }\end{array}$ & - & $?$ & $?$ & - & Yes & $\begin{array}{l}\text { Inter- } \\
\text { mediate? }\end{array}$ \\
\hline $\begin{array}{l}\text { PanAméri- } \\
\text { caine_1 }\end{array}$ & $\mathrm{R}$ & - & $\begin{array}{l}\text { Rockfall on the roadway, } \\
\text { approximately } 1 \mathrm{~m}^{3}\end{array}$ & Calcretization & $?$ & $?$ & $\begin{array}{l}\text { Several blocks on the } \\
\text { pavement along the Rue } \\
\text { Panaméricaine }\end{array}$ & Yes & Limited \\
\hline Delmas32 & $\mathrm{L}$ & $\begin{array}{l}200 \text { houses de- } \\
\text { stroyed, } 60 \text { re- } \\
\text { ported injured }\end{array}$ & $\begin{array}{l}\text { Hillside with a limited } \\
\text { slope }\left(<15^{\circ}\right), \\
\text { over ca. } 30000 \mathrm{~m}^{2}\end{array}$ & - & $\begin{array}{l}\text { Rains / } \\
\text { earthquake }\end{array}$ & 1989 & $\begin{array}{l}\text { Moderately sloping } \\
\text { hillside }\left(<20^{\circ}\right)\end{array}$ & No & $\begin{array}{l}\text { Very } \\
\text { large }\end{array}$ \\
\hline StGérard_2 & B & One house & $\begin{array}{l}\text { Sliding of the banks that } \\
\text { probably carried off the } \\
\text { house }\end{array}$ & $\begin{array}{l}\text { Recent, poorly } \\
\text { consolidated } \\
\text { conglomerate }\end{array}$ & $\begin{array}{l}\text { ravine at } \\
\text { the base? }\end{array}$ & $2010 ?$ & $\begin{array}{l}\text { Influence of the ravine at } \\
\text { the base. No explicit out- } \\
\text { crop of marl }\end{array}$ & Yes & Limited \\
\hline StGérard_1 & $\mathrm{L}$ & - & $\begin{array}{l}\text { Landslide niches some } \\
15 \mathrm{~m} \text { long by } 8 \mathrm{~m} \text { high }\end{array}$ & $\begin{array}{l}\text { Conglomerate overly- } \\
\text { ing marly limestone }\end{array}$ & $\begin{array}{l}\text { Ravine at } \\
\text { the base? }\end{array}$ & $?$ & $\begin{array}{l}\text { Influence of the ravine } \\
\text { at the base? Marly lime- } \\
\text { stone outcropping at the } \\
\text { base }\end{array}$ & Yes & $\begin{array}{l}\text { Limited } \\
\text { to inter- } \\
\text { mediate }\end{array}$ \\
\hline
\end{tabular}

or fracture planes), lithological variations within geological formations, and hydrogeological conditions.

For each geological formation studied, slope thresholds have been defined, mostly calibrated by means of the feedback given by the inventory (Table 1). Thus, a preliminary map was produced thanks to a digital data cross-comparison, with a $5 \mathrm{~m}$ resolution. At each spot, a value was assigned according to the geological nature of the geological formation and the value of the slope. This digital processing yields a preliminary assessment of landslide or rockfall susceptibilities at each point of the study area.

This preliminary map is a precious document to direct the field work and the demarcation of the various zones of hazard.

\subsection{Ground movement hazard map}

The finalized hazard map for ground movements is at 1:10000 scale. It shows the distinction between the two types of ground movements, i.e., landslide and rockfall (Fig. 7). Virtually half of the studied area is concerned with landslides. The rockfall phenomenon, involving less than $10 \%$ of the studied area, is concentrated along the southern boundary of the studied zone as well as on the foothills of the La Selle Mountain range. Landslides remain by far the most frequent and most damaging phenomenon identified.

Four levels of susceptibility of increasing severity have been defined. Their corresponding zonation is as follows:

1. Zones assigned to a hazard that is weak or non-existent. It applies to areas that are flat or with gentle slopes $\left(<5^{\circ}\right)$. These zones are generally not or minimally affected by landslide or rockfall events. The few events that may occur are minor.

2. Zones assigned to a moderate hazard level. They can be subject to landslides of limited (a few hundred cubic meters) or moderate (a few thousand cubic meters) volume. The concerned areas present gentle slopes (between 5 and $10^{\circ}$ on average), made of Miocene geologic formations consisting of marl, marly limestone or silt (formations F4 to F8).

3. Zones assigned to an intermediate hazard level. They are regularly affected by landslides of intermediate intensity (several thousand cubic meters) and, exceptionally, by larger-scale phenomena (several hundred thousand cubic meters), such as the Delmas 32 famous event 


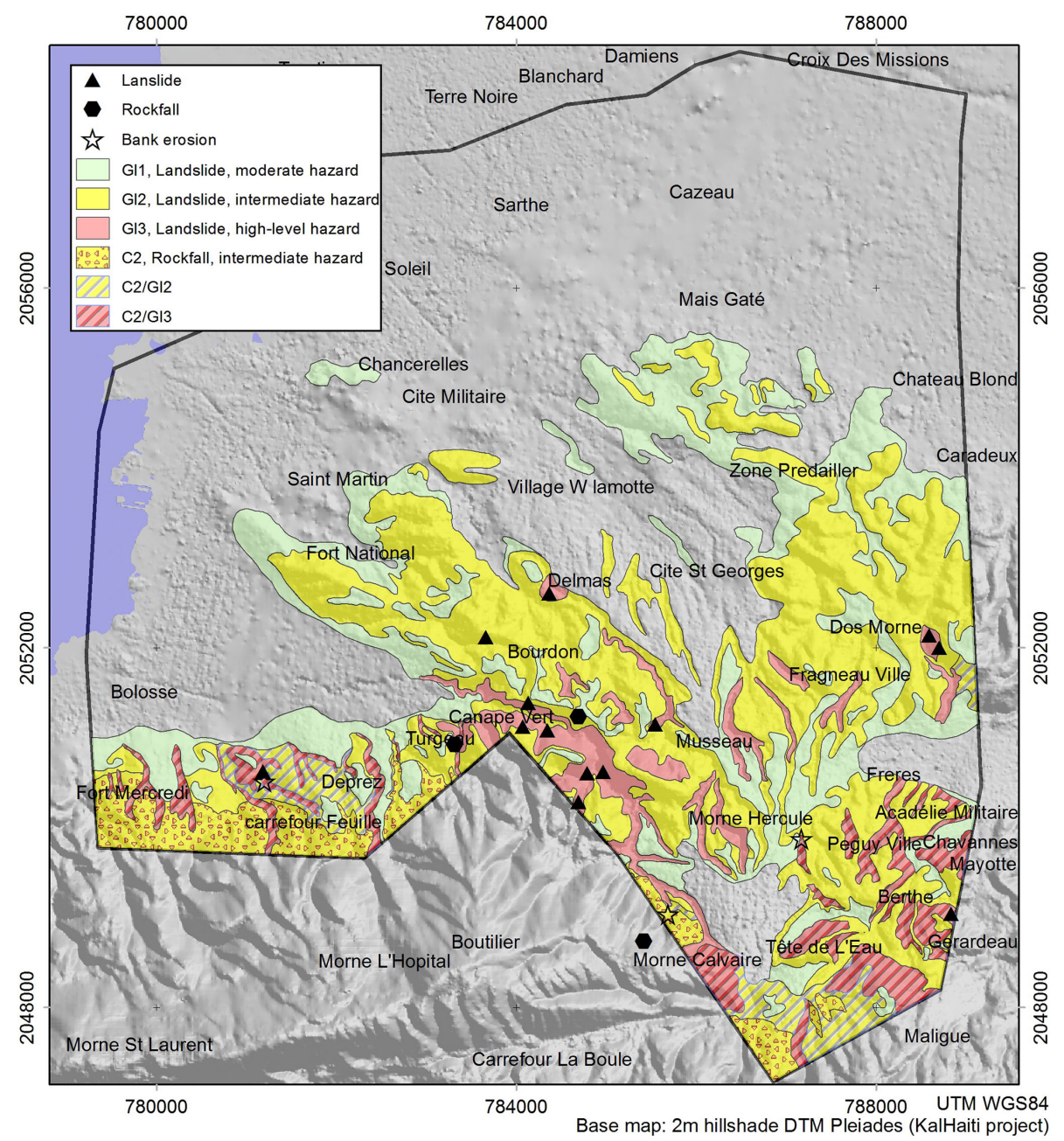

Figure 7. Hazard map of ground movements for the Port-au-Prince metropolitan area.

that caused the destruction of 200 houses in 1989. The concerned areas have either slopes ranging between 10 and $20^{\circ}$, composed of marl, marly limestone, silt or alluvia, or areas are exposed to the propagation of landslides initiated on steeper inclines upslope. Zones with intermediate hazard level can also be exposed to rockfalls. In this case, the terrains involved are rocky, with slopes exceeding $10^{\circ}$, or zones liable to the propagation of rockfall from above.

4. Zones assigned to a high level of hazard prone either to frequent superficial landslides or to large-scale events (active or potential). They are characterized by intermediate to steep slopes with unfavorable geological conditions or land-use factors (typical configurations of the historical well-known landslides like Vivy Mitchell 1 and 2, Musseau), or they are concerned with massive landslide propagation from higher altitude. Thus, included under this category, we find small rivers and footslopes, which are receptacles for materials that have slipped off slopes and can be remobilized in the rivers as mudflows.

\section{Implications for preventive seismic recommendations}

Within the framework of the seismic microzonation project, the next step was to complete these geological data with geotechnical and geophysical investigations, and then to map the ground responses to seismic activity. Moreover, this next step has taken into account the topographical conditions of the city of Port-au-Prince. A first comparison between the distribution of damage caused by the 2010 earthquake (UNOSAT, 2010) and the lithological and topographic data shows a concentration of damage to the right of topographical buttes on the one hand, and on the edge of the coastline above the alluvial marine deposits (Fig. 2, see F10-ma) on the other hand. 
The map of the active faults and the hazard map of ground movements, which are two full components of the seismic microzonation survey, were integrated into the final products.

The geological study of Port-au-Prince reveals that the capital of Haiti is located near or directly over two active fault systems (Fig. 2), which have been taken into account in the hazard risk assessment: (i) the EPGFZ, which bounds the southern limit of the Port-au-Prince urban area, and (ii) the $\mathrm{N} 110^{\circ} \mathrm{E}$ faults. The latest fault set corresponds highly to the south-easterly extension of the reverse faults located in the Gulf of Gonâve and which connects to the EPGFZ to the east. The $\mathrm{N} 110^{\circ} \mathrm{E}$ faults system mapped on land has a maximum length of $15 \mathrm{~km}$ but, as indicated by offshore geophysical data, this system almost certainly extends WNW into the Gulf of Léogâne. Tectonic deformations in terrains, dated presumably to the middle or recent Quaternary, are observed at several locations along these faults. Taken in conjunction with the morphostructural data, it indicates a reverse left-lateral displacement, associated with a mean horizontal slip on the order of $0.6( \pm 0.2) \mathrm{mm} \mathrm{yr}^{-1}$.

Thus, as a main result of the study, in the context of the Port-au-Prince metropolitan area, it is highly recommended that the construction of high-stake buildings such as schools, hospitals, disaster relief centers or structures of strategic importance in the vicinity of active faults be prohibited.

Concerning the ground movement hazard, each specific zone identified on the hazard zonation map (Fig. 7) is subject to specific recommendations (measures) designed to take the ground movement hazard into account in existing constructed areas or for future urban land-use development. No recommendation is made for zones of low hazard level. It just makes sense to plan and to build according to appropriate construction rules. The zones associated with a moderate, intermediate or high hazard level are governed by specific recommendations which depend of the hazard level.

\section{Conclusions}

The geological study performed within the framework of the seismic microzonation project of the metropolitan area of Port-au-Prince has enabled the environmental context of the deposits of the Miocene and Pliocene geological formations to be established. They are marine deposits, either deep or sublittoral, which are characteristic of lowenergy environments and occasionally showing sudden inputs of detrital materials. These inputs are turbidites related to the continual activation of the southern boundary faults of the Port-au-Prince Plain during the Miocene and Pliocene. Moreover, the study confirms the presence of several active faults that include not only the EPGFZ bounding the Port-auPrince metropolitan area to the south, but also faults trending $\mathrm{N} 110^{\circ} \mathrm{E}$ that are directly visible within it.

There are still uncertainties. Among them, the age of the lithological units should be confirmed by chronostratigraphic dating. It is also necessary to determine the relationships and contours for units F6 to F8, which are characterized by specific environments of deposition. Furthermore, the deposit of the F9 unit needs to be determined with greater precision, notably concerning its relationship with the upstream portion of the catchment area. Recommendations are made for taking into account the hazard of surface rupture along active faults, but it would be preferable to reduce uncertainties on the fault traces and to better understand the seismogenic potential of these structures. To this end, the analysis could be pursued by local geophysical studies and paleoseismic trench investigations.

The hazard map of ground movements at a scale 1:10000 has been made mainly on the basis of the geological map and an inventory of past events. It takes into account both the initial predisposition and the propagation of instabilities, while also distinguishing between landslide and rockfall phenomena. The results will be directly integrated into the seismic microzonation map of the metropolitan area of Port-auPrince.

The location and characterization of lithological or topographical site effects is the aim of another phase of the seismic microzonation of Port-au-Prince. To this end, the implemented lithological map will be an essential input.

Acknowledgements. The authors wish to thank Cl. Flores, the anonymous referee and J. P. Rançon for their constructive comments. This work is one of the results of the project of seismic microzonation of the metropolitan area of Port-au-Prince, funded by the Ministry of Public Works, Transport and Communications of the Republic of Haiti. The authors also thank the ANR Kal-Haiti project (2010 HAIT 008 01; http://kal-haiti.kalimsat.eu) for the provision of satellite images and DTM data.

Edited by: O. Katz

Reviewed by: $\mathrm{Cl}$. Flores and one anonymous referee

\section{References}

Bachhuber, J. L., Rathje, E. M., Cox, B. R., Dulberg, R. A., Kottke, A., and GEER Team: Carte géologique de Port-au-Prince, 2010.

Bakun, W., Flores, C., and Ten Brink, U.: Significant earthquakes on the Enriquillo fault system, Hispaniola, 1500-2010: Implications for seismic hazard, Bull. Seism. Soc. Am., 102, 18-30, 2012.

Butterlin, J: Géologie générale et régionale de la République d'Haïti - Travaux et Mémoire de l'Institut des Hautes Etudes de l'Amérique Latine, Paris, 1960, une carte géologique hors texte à $1: 250000$, in color, 1958, 194 pp., 1960.

Calais, E., Freed, A. Mattioli, G., Amelung, F., Jónsson, S., Jansma, P., Hong, S. H., Dixon, T., Prépetit, C., and Momplaisir, R.: Rupture d'une faille jusqu'ici inconnue pendant le séisme de 2010 à Haïti, Nat. Geosci., 3, 797-799, 2010.

Douilly, R., Symithe, S., Haase, J., and Calais, E.: Les répliques du séisme du 12 janvier 2010, Bulletin spécial no 01 de l'Unité Technique de Sismologie (UTS) du Bureau des Mines et de 
l'Energie (BME), période du 12 janvier 2010-12 janvier 2012, 2012.

KalHaiti, SERTIT, CNES: Production d'un Modèle Numérique de Surface - Acquisition Pléiades tristéréoscopique - Port-auPrince, Haïti, 2012.

Mann, P., Taylor, F, Edwards, R., and Ku, T.: Actively evolving microplate formation by oblique collision and sideways motion along strike-slip faults: An example from the northeastern Caribbean plate margin, Tectonophysics, 246, 1-69, 1995.

Mann, P., Calais, E., Ruegg, J. C., DeMets, C., Jansma, P. E., and Mattioli, G. S.: Oblique collision in the northeastern Caribbean from GPS measurements and geological observations, Tectonics, 21, 1057, doi:10.1029/2001TC001304, 2002.

Mercier de Lépinay, B., Deschamps, A., Klingelhoefer, F., Mazabraud, Y., Delouis, B., Clouard, V., Hello, Y., Crozon, J., Marcaillou, B., Graondorge, D., Vallée, M., Perrot, J., Bouin, M. P., Saurel, J. M., Charvis, P., and St-Louis, M.: The 2010 Haiti earthquake: A complex fault pattern constrained by seismologic and tectonic observations, Geophys. Res. Lett., 38, L22305, doi:10.1029/2011GL049799, 2011.
Momplaisir, B. M.: Contribution à l'étude géologique de la partie orientale du massif de la Hotte (presqu'̂̂le du Sud d'Haïti), Synthèse structurale des marges de la presqu'île à partir des données sismiques, Thèse Univ. Pierre et Marie Curie, Paris 6, 1986

Momplaisir, B. M. and Boisson, D.: South-East sheet (Port-auPrince) - Carte géologique à $1 / 250000$ de la République d'Haiti (in 4 sheets), B.M.E. (1982-1988), 1987.

Pubellier, M., Mauffret, A., Leroy, S., Vila, J. M., and Amilcar, H.: Plate boundary readjustment in oblique convergence: Example of the Neogene of Hispaniola, Greater Antilles, Tectonics, 19, 630-648, 2000.

UNOSAT, Poster: Comprehensive building damage assessment fort Port-au-Prince commune, Haiti (version 2), Daage analysis of individual buildings based on post-earthquake aerial photos and pre-earthquake satellite imagery, UNITAR programm (United Nations Institute for Training and Research), available at: http: //www.unitar.org/unosat/node/44/1442, last access: June 2014, 2010. 